\title{
Loan to Value Caps and Government-Backed Mortgage Insurance: Loan-Level Evidence from Dutch Residential Mortgages
}

\author{
Leo de Haan ${ }^{1,2} \cdot$ Mauro Mastrogiacomo $0^{1,3,4}$
}

Published online: 17 June 2020

(c) The Author(s) 2020

\begin{abstract}
Using loan level data on mortgage loans originated by Dutch banks during 1996 to 2015, we analyse the determinants of the incidence of non-performance. We find that both the originating loan-to-value ratio (OLTV) and the debt-service-to-income ratio are significantly positively associated with the probability of non-performance. The results suggest that mortgages with government-loan-guarantees perform better. Moreover, several mortgage loan and borrower characteristics, such as the (interestonly) loan type and the underwater status of the borrower, increase credit risk. Our model predictions suggest a novel policy implication: in order to avoid acceleration of non-performance probabilities, the OLTV-limit should be set to about 70-80\% for uninsured mortgages, and to about $90 \%$ for those with mortgage insurance.
\end{abstract}

Keywords Credit risk $\cdot$ Mortgage loans $\cdot$ Loan to value $\cdot$ Loan guarantees $\cdot$ Mortgage insurance

JEL Classification $\mathrm{G} 20 \cdot \mathrm{G} 21 \cdot \mathrm{H} 81$

We thank Dennis Olson, Conor O'Toole, and participants of the DNB seminar (May, 2019) and the World Finance Conference (July, 2019) for useful comments and advice. The views expressed are those of the authors and do not necessarily reflect the positions of DNB or CBA.

Mauro Mastrogiacomo

m.mastrogiacomo@dnb.nl

1 De Nederlandsche Bank, Amsterdam, The Netherlands

2 Centrale Bank van Aruba, Aruba, The Netherlands

3 Vrij Universiteit Amsterdam, Amsterdam, The Netherlands

4 Netspar, Tilburg, The Netherlands 


\section{Introduction}

A growing amount of literature is currently focusing on the relationship between indebtedness and credit risk. Excessive indebtedness, combined with nonrecourse loans ( $\mathrm{Li}$ and Oswald 2017), has been one of the main drivers of the recent financial crisis, as it induced defaults and a number of negative externalities, such as a drop in consumption (Mian and Sufi 2009) and asset prices (Mian et al. 2013) that spread from the US to most economically developed countries.

Macroprudential policy, in the form of setting LTV and DSTI caps, is being used in order to prevent such externalities (Geanakoplos 2009). Wong et al. (2011) discuss the role of maximum LTV ratios on mortgage delinquency. Also Gerlach-Kristen and Lyons (2018) show that defaults tend to be more common in countries with high LTV ratios.

Yet it is unclear how to calibrate these caps (Galati and Moessner 2018). Most studies focus on cross country comparisons and rely on differences across countries, to estimate the relationship between LTV and DSTI-caps and risk. These studies are either conducted using macro data (Stanga et al. 2017) or micro data (Japelli et al. 2008). The first type of data has the advantage of an easier international comparability, while it misses the possibility to estimate any causality by considering units being exposed to a common treatment. Country micro data, on the contrary, can pin-down a treatment and control group, but in the case of Japelli et al. (2008), for instance, the survey nature of the data does not allow a specific study of tail-risk, which is a problem as defaults in several countries occur in $<3 \%$ of the relevant population.

In this sense, replacing survey data with supervisory micro data would be a better choice, as the tail risks are better represented. Evidently such data is not easily suited for international comparisons. Kelly and O'Toole (2019) use a double trigger default model to identify threshold effects showing that Buy-to-Let mortgage loan defaults increase with the OLTV ratio and fall with the originating debt service ratio measured as rental value to instalment at origination. This is the only study we have found that investigates the issue using loan level data. Specifically, they use 2014 Q4 Buy-to-Let loan level data of Irish banks headquartered in the UK, representing 2 percent of the UK mortgage market.

We also have loan level data for the Netherlands. The Netherlands has been among the countries with the steepest rise of mortgage debt of households (Ronald and Dol 2011; Lea 2011). Despite the high households' mortgage debt to GDP ratio, the non-performance rate (i.e., arrears and foreclosures or defaults) for Dutch residential mortgage loans has been low compared to other countries. However, the relatively high loan to value ratios for Dutch residential mortgages make the residual debt risk and the potential loss given default large. This in turns affects expected losses and thus also capital requirements of banks (Japelli et al. 2008; Stanga et al. 2017). These authors find that lower regulatory LTV ratios and institutional quality, such as judicial efficiency, bankruptcy regulation and property protection (notably lender recourse on borrowers), are statistically significantly associated with a lower share of mortgage arrears in their sample of 26 countries over the period 2000-2014. 
Using loan level data on residential mortgage loans of all Dutch banks originating from 1996 to 2015, we analyse the determinants of the incidence of non-performance. We include both the originating loan-to-value ratio (OLTV) and the current debt-service-to-income ratio (DSTI) among the explanatory variables, while in stress tests models, typically, the DSTI only is associated to the probability of nonperformance. We also exploit a recent tax reform to the mortgage interest deduction in order to bring additional heterogeneity in the computation of the DSTI (see "Appendix B" for details about this computation). Moreover, several mortgage loan and borrower characteristics, such as the (interest only) loan type and the underwater status of the borrower, are included. One of our novel contributions is that we also examine the effect of residual debt insurance on non-performance of mortgage loans.

We suggest to set the OLTV limit such that non-performance does not accelerate; this appears to be in our data at a level of $70-80 \%$ for uninsured loans. We also discuss the possibility to tailor-make the OLTV limit depending on risk characteristics, such as acquiring a residual debt insurance. In this case it appears that the OLTVcap could be as high as $90 \%$.

When macroprudential limits are exceeded, the institutional setting becomes relevant for the onset of possible market failures. In a non-recourse system, the effect of macroprudential instruments is limited by moral hazard, for instance in the case of strategic defaults (Guiso et al. 2013). In a full recourse system instead, a similar limitation could arise in the presence of mortgage insurance (Kim et al. 2018).

We extend on previous studies by using a dataset for the Netherlands that contains 1.5 million or about $90 \%$ of the residential mortgage loans underwritten by the Dutch banking sector. This highly representative sample has the advantage of allowing identification of specific subgroups, and to focus on tail events, such as arrears and defaults or foreclosures, that are barely observed in survey data. ${ }^{1}$ The Dutch data provide a unique opportunity to investigate the effect on the rate of non-performance of government backed residual mortgage debt insurance. This insurance is called the Nationale Hypotheek Garantie (NHG). As noted by Lea (2011), the mortgage insurer is a government-owned fund, the so-called Homeownership Guarantee Fund (in Dutch: Waarborgfonds Eigen Woning). The fund is a private institution with fallback agreements with the national and municipal governments. These agreements form the basis for interest-free loans to the Fund from the national and municipal governments at times when its assets are no longer sufficient to meet claims. This means that the Fund is able to comply with its payment obligations at all times. As a result, the Dutch central bank (in Dutch: De Nederlandsche Bank (DNB)) considers the NHG as a government guarantee. According to the figures shown by Lea (2011), mortgage default rates in the Netherlands are among the lowest internationally. This raises the question whether the low default rate is related to the NHG. Debt insurance may have significant effects. For example, De Haan (2003) finds that NHG affects monetary transmission, in the sense that a bank lending channel is operative

\footnotetext{
${ }^{1}$ For example, the ECHP survey data used by Japelli et al. (2008) include only 5000 Dutch mortgage loans.
} 
in the Netherlands but only for unsecured lending and not for secured lending, possibly because loans with NHG get special treatment by banks.

The plan of the paper is as follows. The next section describes the data. The research methodology, followed by a presentation of the results are presented in the two subsequent sections. The last section concludes.

\section{Data and Descriptive Analysis}

As mentioned above, the total outstanding mortgage debt in the Netherlands is high. It has quadrupled from around 28\% of GDP at the beginning of the 1980s to around $100 \%$ just before the Financial Crisis and since then decreased somewhat to $90 \%$ in 2017 (Fig. 1a). Moreover, the Dutch households' balance sheet is relatively 'long'. Against the high mortgage debt, on the liabilities side, are mostly illiquid assets on the assets side, consisting of housing wealth and the value of compulsory occupational pension rights deposited with pension funds (Fig. 1b). The illiquid nature of wealth and the high mortgage debt make the Dutch economy, and especially private consumption, relatively sensitive to financial shocks on the housing market and on financial markets (DNB 2018).

De Nederlandsche Bank (DNB) started in 2012 the collection of the DNB loan level data (LLD). This initiative is based on the RMBS template used by the European Central Bank (ECB), within the framework of their $100 \%$ transparency policy on securitized loans, available through the European Data Warehouse (EDW). The LLD is an extension of the ECB data. The EDW version of the data only contains securitized loans, a minor fraction of (typically) low-risk loans. The LLD used in this paper instead also includes the back-books of banks, with their entire stock of loans.

Coverage of the LLD and comparability with other sources is high (Mastrogiacomo and Van der Molen 2015). The data contains about $80 \%$ of all loans of Dutch households, and more than $90 \%$ of those issued by Dutch banks to residents. The composition by bank is given in Table 1 .

The data are reported on quarterly basis by the main 12 Dutch banks, and the collection started in the fourth quarter of 2012. Each wave contains about 6 million loans, issued to 3 million borrowers. This means that on average every Dutch borrower combines at least 2 loans.

We use the 2016Q2 wave of the LLD. Relevant to this paper are several indicators, such as the originating Loan to Value ratio (OLTV), i.e. the LTV ratio at origination of the loan, and household income at origination of the loan, which we use to compute the current mortgage debt service to income ratio (DSTI), the loan type (interest-only or not), and the status of each loan (performing or non-performing, i.e. in arrear or foreclosed).

Table 2 summarizes some relevant mortgage characteristics that are elicited using the LLD. The table shows several indicators revealing the main features of the Dutch mortgage market. In the LLD, it is for instance possible to elicit the value of the saving deposits pledged to the mortgage. This means that the mean outstanding debt is a net concept, as these deposits have been subtracted. This is important 
A Dutch banks' total outstanding amount of mortgage loans, in \% GDP $120 \%$

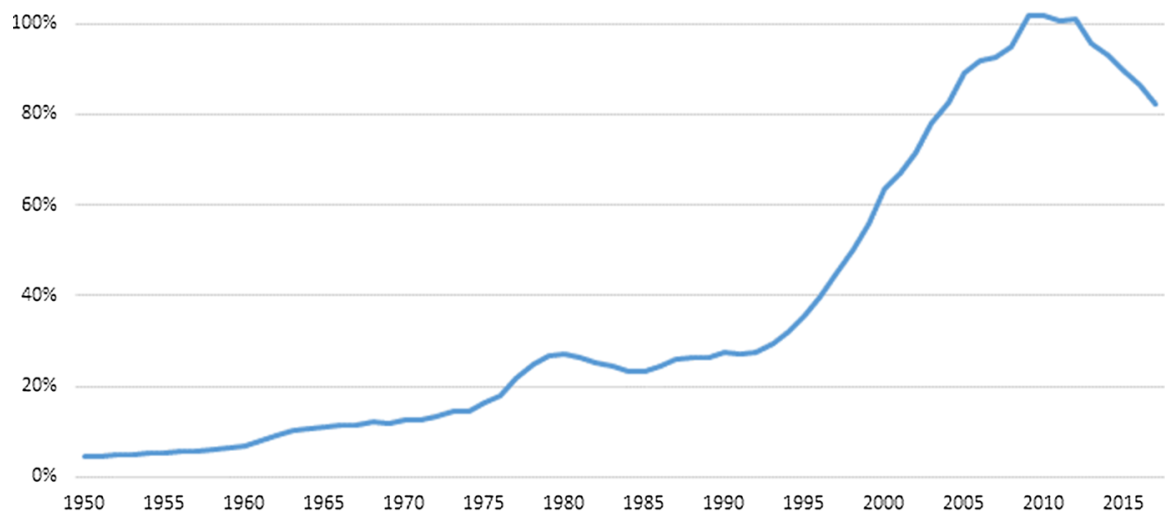

B Balance sheet composition of Dutch households, in \% GDP
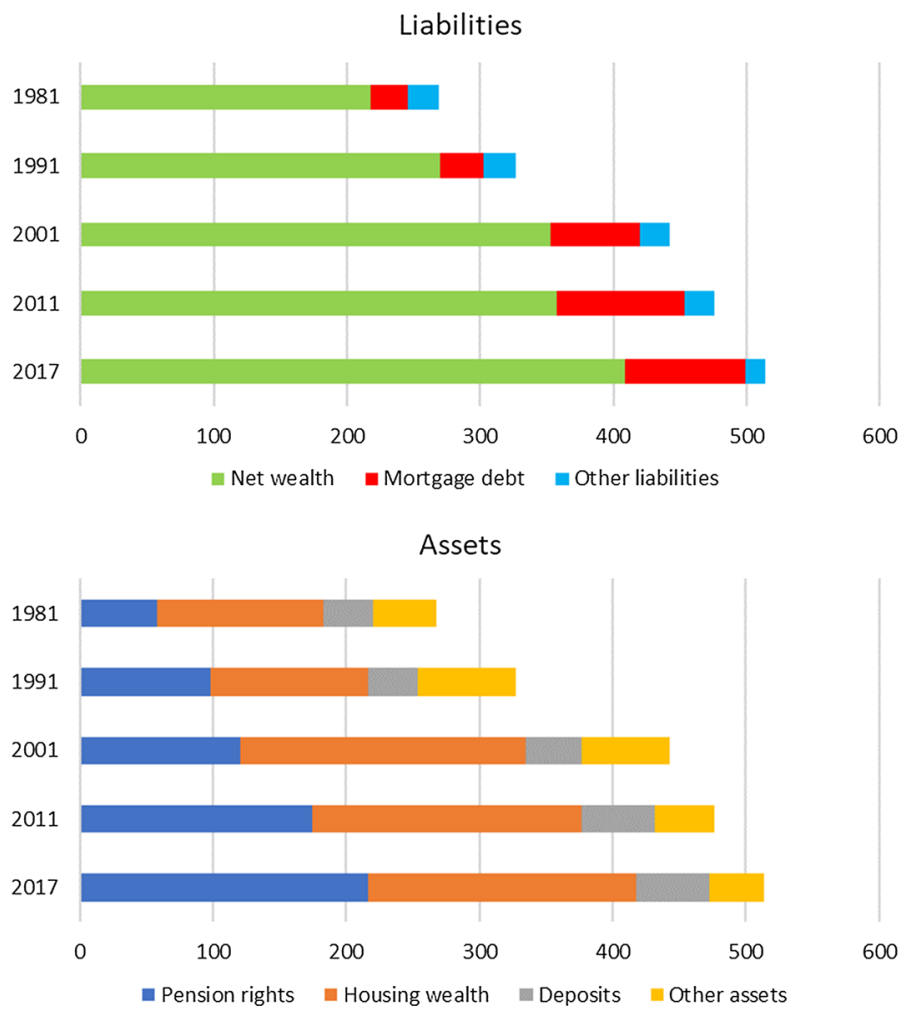

Fig. 1 Mortgage debt ratio and balance sheet of Dutch households. a Dutch banks' total outstanding amount of mortgage loans, in \% GDP. Source: Kakes et al. (2017) and DNB. b Balance sheet composition of Dutch households, in \% GDP. Source: Statistics Netherlands 
Table 1 Sample composition, by underwriting bank
Bank Percentage of number of borrowers

\begin{tabular}{lr}
\hline ABN Amro Bank & 19.9 \\
Achmea & 3.1 \\
Aegon & 2.0 \\
ING & 32.8 \\
NIBC & 2.3 \\
Nationale Nederlanden & 1.4 \\
Rabobank & 38.3 \\
Van Lanschot & 0.2 \\
Total & 100.0
\end{tabular}

The LLD is provided by 12 banks. In this study, we only keep the 8 banks that provide all borrowers' background information needed. The banks dropped show similar non-performance rates

Table 2 Descriptive statistics

Mean current value of a property

Median current value of a property

Mean outstanding mortgage debt (per borrower)

Mean savings deposit (SD) pledged to mortgage

Mean originating LTV ratio whole sample

Mean mortgage interest rate, whole sample

Share of underwater mortgages

Share of NHG mortgages

Mean home equity of an underwater mortgage (including SD)

Median home equity of an underwater mortgage (including SD)

Mean share of interest only mortgage at origination

Share of non-performing loans

Of which

Share of loans with arrears

Share of defaults or foreclosures

Current value of a property is either updated using a price index relative to the original value or reappraised. Originating Loan to Value ratio is the Loan To Value ratio at origination of the loan. For second line loans this is the combined or total OLTV. The underwater status is a dummy equal to 1 if the current valuation amount is larger than the current principal. Definition net of pledged saving accounts (also called saving deposits (SD)), when these are proxied using inception date rather than origination date. We apply a $2 \%$ haircut to the current valuation amount, which is an indexed value relative to the original valuation using local indexes provided by Statistics Netherlands. Share of interest only (IO) loans is defined using the sum of these loan types divided by total debt. IO loans are separately identified as being a bullet loan. These loans do not amortize and thus do not have a maturity date. Arrears defined as: total payments due to date minus total payments received to date minus any amounts capitalized. Foreclosure (or default) is established before application of sale proceeds and recoveries 

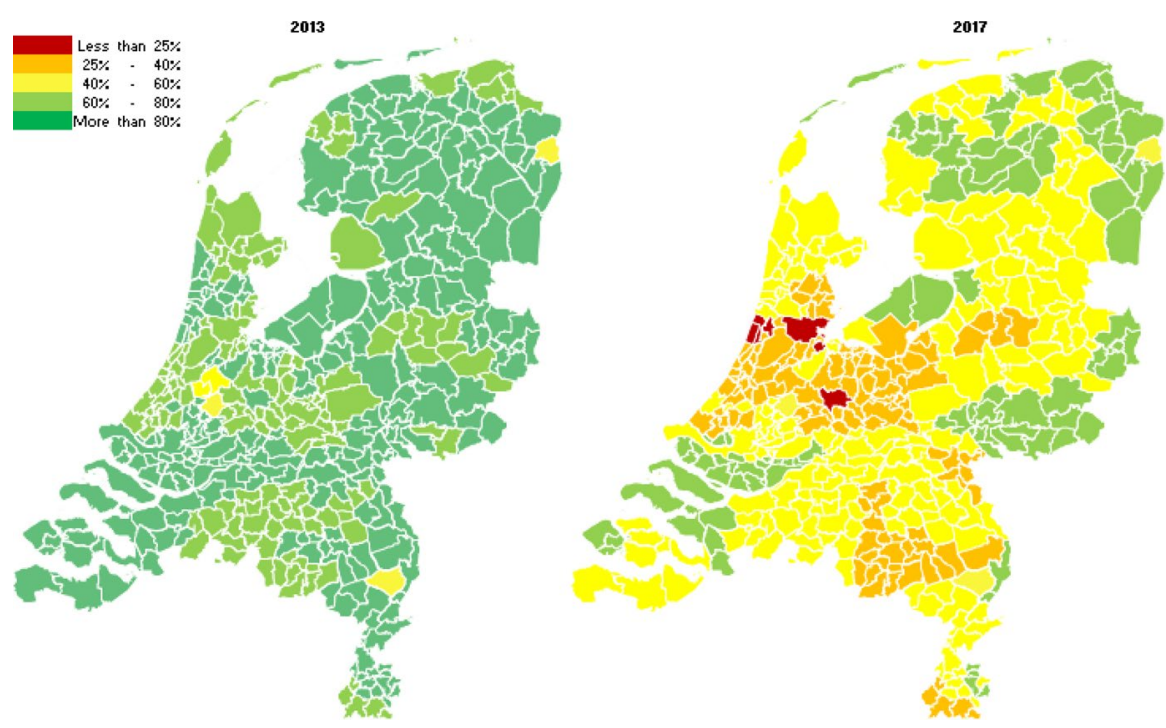

Fig. 2 Share of starters with NHG is decreasing

to keep in mind, because technically these deposits are pledged in order to provide full redemption only at maturity. However, in the LLD, these are treated as perperiod amortizations. Further the table shows the OLTV for the whole stock. Due to expanding monetary policy, the interest rate for an insured loan with a 10 years reset period (the most common product in the Netherlands) has dropped from about $4 \%$ to $<2 \%$, however it will take time before this reduction is spread to all households, that is why the mean interest rate presented here is higher. This is possibly due to several mitigants that protect households from interest rate fluctuations. It is very important to have information about the loan level interest rate, as we use it to compute the DSTI (see "Appendix B"). With the reduction of the interest rate, also reset-periods have become on average longer and have now passed the 10 years mark. Finally, the table shows the reduction in risk elicited by several other characteristics, such as the share of underwater mortgages, of interest only loans, and of non-performing loans and their balances.

The data also allows zooming into two specific features of the Dutch mortgage market. First, upon purchasing a house with a value below a legislated threshold, new home-owners can insure their loan against the risk of residual debt. This insurance, as mentioned in Sect. 1, is called a Nationale Hypotheekgarantie (NHG). A default is not strictly needed for the insurance to be activated. Those selling a property with an underwater mortgage, can apply for reimbursement of residual debt. The NHG will then reimburse the bank and become the sole creditor of the mortgage owner. If specific conditions are met, the NHG will pardon debt fully if the mortgage was amortizing and partially if not. The specific conditions to qualify for pardoning depend on the reason for selling the house. If this was necessary due to unemployment, disability, death of a partner or divorce, NHG will pardon. Since 2014 also an affordability test can be carried out in specific cases. Figure 2 shows 


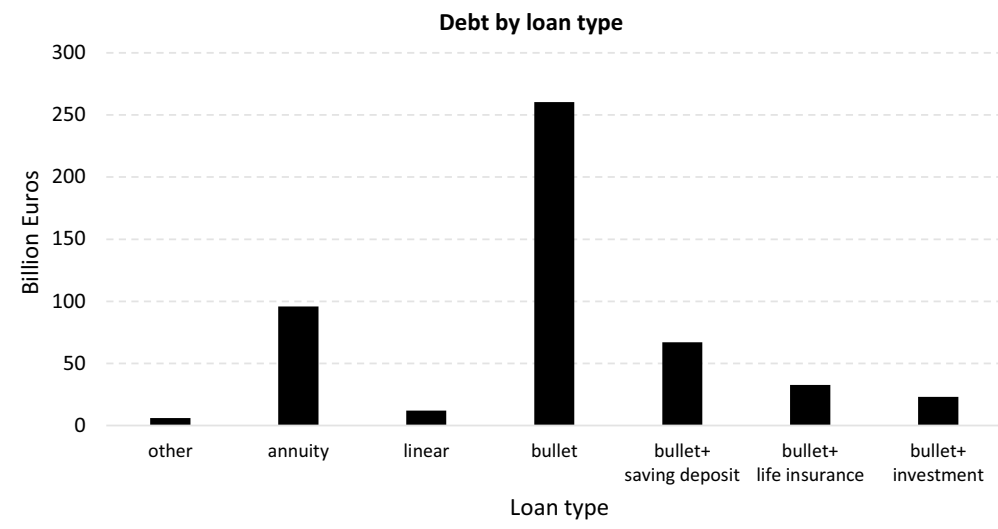

Fig. 3 Debt by loan type

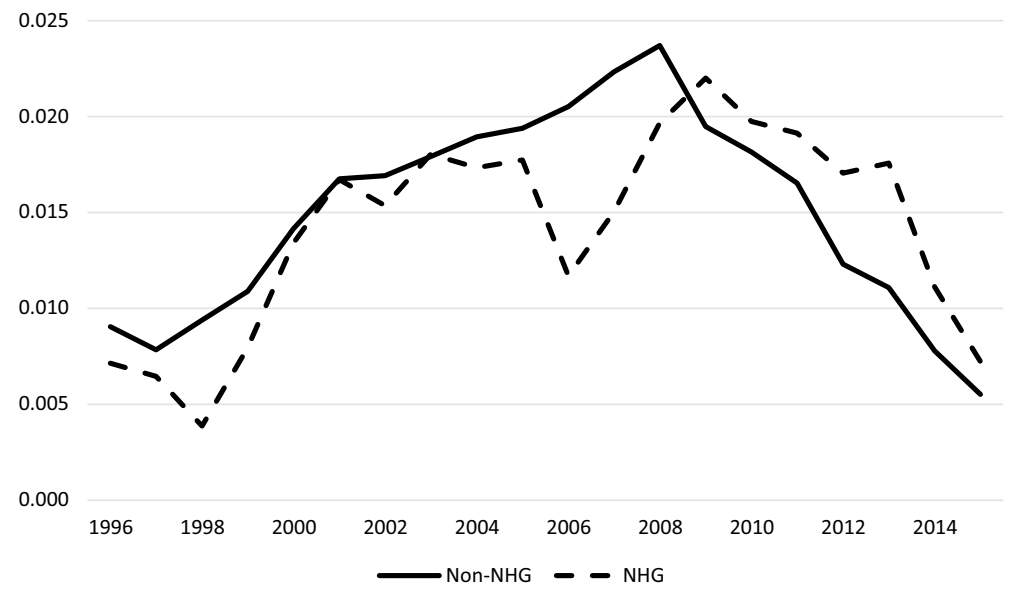

Fig. 4 Non-performing rate for mortgage loan with and without NHG, by year of loan origination

that participation in this scheme has been historically very popular among starters, but that recently this has reduced in the whole country (due to increasing prices, mostly in large municipalities such as Amsterdam, and decreasing qualification thresholds). In our sample, $33 \%$ of loans have an NHG.

Second, in the past 20 years, many interest-only (or so-called 'bullet') loans have been sold. Figure 3 shows that more than $55 \%$ of loans outstanding are of such type, and thus do not contractually amortize. The LLD also allows calculating the share of interest-only loans applicable to each borrower. It appears that only one third of the borrowers has a fully interest-only loan, while about half combines such loans with (semi) amortizing loans. The group of fully interest-only borrowers has somewhat lower outstanding debt, is older and has used the mortgage more often for homeequity extraction (Mastrogiacomo and van der Molen 2015). 
We define a mortgage as non-performing (NP) if there is an arrear or a foreclosure or default in any of the underlying loans. Figure 4 shows the NP rate for NHGloans and non-NHG loans, by year of loan origination. The NP rate of non-NHG loans increased from $0.9 \%$ in 1996 to $2.4 \%$ in the global financial crisis year 2008 and subsequently decreased to $0.6 \%$ in 2015 .

Figure 4 also shows that the NP rate of non-NHG participants before the crisis was in some years significantly higher than the dashed line for NHG participants. The two lines cross after 2009. After the crisis, NHG-loans defaulted more often. Two possible explanations could be given for this evidence. Kim et al. (2018) discuss the possibility of moral hazard, as the insurance reduces the consequences of a default for the insured. This would in principle lift the dashed line up. But also changes in institutions could be partly responsible. In 2010, NHG requirements (such as comply with LTI rules) became compulsory also for non-NHG loans, thus reducing their risk. This second effect could lower the solid line.

\section{Methodology}

In this section, we first introduce the potential determinants of the probability to non-perform that we will test in the empirical model. Next, we present our empirical model of the probability to non-perform. In order to treat all observations consistently, we arrange the data at borrower level. So, the borrower is our unit of analysis. This is an obvious choice, as the main triggers in our model, OLTV and DSTI, are not defined at loan level. We thus use the detailed loan level information to construct the following variables at borrower level.

\subsection{Determinants of Non-performing Status}

1. The originating Loan to Value ratio (OLTV) at origination of the mortgage is defined as the sum of all principals of all loans of a borrower divided by the value of the house. Kelly and O'Toole (2019), using loan level data for buy-to-let mortgages, find that the greater the size of a mortgage in relation to the value of the house at the time of the origination of the loan, the higher is the probability of a future NP. Typically, stress-test models assume that LTV ratios only affect loss given default (LGD), but when mortgages are underwater defaults may increase (for instance due to strategic defaults; see, e.g., Ampudia et al. 2014).

2. The mortgage debt service to income ratio (DSTI) is defined as all payment obligations of the loans owned by a borrower divided by the borrower's income. This is partly affected by recent tax reforms that add heterogeneity across groups and will help the identification of the effect. For the definition of DSTI we refer to "Appendix B". We expect a positive association between this variable and non-performance.

3. NHG is a binary indicator of the presence of residual debt insurance, as discussed in Sect. 2. This is equal to 1 if a borrower insures any of his loans against the risk of residual debt upon selling the house. The borrower pays a lump-sum-fee 
to the foundation when taking the loan (in 2016 this is 1\%). On the other hand, lenders grant to borrowers with insurance a discount on the mortgage interest rate (between 0.3 and 0.6 percent point). The insurance can be obtained for loans up to a maximum amount ( $€ 245.000$ in 2016). The insurance can be bought only by borrowers with a proportion of income which is spent on housing below a certain limit ${ }^{2}$ : hence, the insurance signals that there is a solid income base for the debt service. Also defaulting or foreclosing is not strictly necessary to obtain a reimbursement, as also a downsizer qualifies. Our assumption therefore is that the presence of NHG diminishes the risk of becoming non-performing.

4. The age (at origination) of the loan-applicant in years is assumed to have a negative relationship with non-performance as older borrowers, being more advanced on their financial life-cycle, often are wealthier and more credit worthy than younger ones. They are also survivors in the data, thus more likely to not default.

5. The underwater status of the mortgage (or, so-called 'negative equity') is a binary indicator telling whether the outstanding principal of all loans of a borrower is greater or not than the current value of the house. Households facing the dual trigger of affordability problems and negative equity are more likely to go into longer-term arrears (Gerlach-Kristen and Lyons 2018).

6. The self-employment status of the loan-applicant is a binary indicator telling whether the borrower at the time of loan origination was self-employed or not. We assume that self-employed are more at risk of income fluctuations and therefore loans to self-employed run higher risk to not perform. $8 \%$ of loan applicants in the data are self-employed.

7. The purpose of the loan is also assumed to affect the non-performing status. We look at the purpose of a borrower's largest loan if there are more than one loan. When the mortgaged house is partly used for commercial purposes, credit risk is expected to be higher, as one is more at risk of income fluctuations.

8. An interest-only loan is a loan without contractual amortization during the loan term. We assume that interest-only loans have more credit-risk than loans which are repaid during the loan term, as the former are more exposed to interest rate shocks. We use the share of interest-only in the total mortgage debt of the borrower.

Table 3 gives the mean and median values of the explanatory variables for the $1,590,494$ borrowers in the sample, split up according to whether their mortgage is insured by NHG or not. From these summary statistics, some tentative inferences can be made. Loan applicants with an NHG are relatively young, less often self-employed, and less frequently using their house partly for commercial purposes. NHG holders have higher OLTV and DSTI ratios and their houses are more often underwater. Nevertheless, their non-performance rate is comparable

\footnotetext{
${ }^{2}$ DSTI-caps (also called LTI-caps in the Netherlands as an annuity is always assumed) are comply-orexplain rules. This means that some exceptions are allowed and some borrowers can borrow more than the DSTI limit allows. However, NHG will not accept these borrowers as costumers. Only compliers are accepted. In the LLD we observe about $10 \%$ of non-compliers to the DSTI cap for the whole sample.
} 
Table 3 Residential mortgage loan characteristics, with and without NHG

\begin{tabular}{|c|c|c|c|}
\hline & Non-NHG & NHG & $\begin{array}{l}\text { Test of differences in } \\
\text { means (medians); } \\
p \text { - values }\end{array}$ \\
\hline Non-performance dummy & $0.017(0)$ & $0.016(0)$ & $0.000 * * *(0.000 * * *)$ \\
\hline Originating Loan to Value ratio & $0.760(0.791)$ & $0.935(1.000)$ & $0.000^{* * *}\left(0.000^{* * *}\right)$ \\
\hline Debt service to income ratio & $0.090(0.088)$ & $0.126(0.129)$ & $0.000 * * *(0.000 * * *)$ \\
\hline Age loan applicant & $42.467(42)$ & $34.698(33)$ & $0.000^{* * *}\left(0.000^{* * *}\right)$ \\
\hline Under-water status (dummy) & $0.214(0)$ & $0.318(0)$ & $0.000^{* * * *}\left(0.000^{* * *}\right)$ \\
\hline Self-employment status loan applicant (dummy) & $0.105(0)$ & $0.033(0)$ & $0.000 * * *(0.000 * * *)$ \\
\hline Interest-only loan share & $0.609(0.647)$ & $0.292(0.350)$ & $0.000 * * *(0.000 * * *)$ \\
\hline House partly commercially used (dummy) & $0.004(0)$ & $0.001(0)$ & $0.000^{* * *}\left(0.000^{* * *}\right)$ \\
\hline Number of borrowers & $1,058,775$ & 531,719 & \\
\hline
\end{tabular}

First two columns: mean values with median variables within parentheses. Non-performance joins arrears and foreclosures. Originating Loan to Value ratio is the Loan To Value ratio at origination of the loan. For second line loans this is the combined or total OLTV. Debt service to income ratio (DSTI) only takes mortgage debt into account (see "Appendix B" for more details). Age loan applicant is the age at origination of the mortgage. The underwater status is a dummy equal to 1 if the current valuation amount is larger than the current principal. Self-employment is measured at loan application. Share of interest only (IO) loans is defined using the sum of these loan types divided by total debt. IO loans are separately identified as being a bullet loan

${ }^{a} p$ values are for t-tests of differences in means and for Pearson Chi square tests of differences in medians, respectively. $* * *$ Indicates statistical significance at $1 \%$

or even somewhat lower (on average 1 percentage point) than that of their counterparts without an NHG. Also, NHG holders use interest-only loans less often.

\subsection{Empirical Model}

We employ a logit model of the probability of a borrower to become non-performing. Non-performing status $N P$ can be 1 or 0 (either a case of default/arrear or not). The logit model assumes that the probability of $N P=1$ is a logistic function of the linear expression $\left(\beta_{0}+\beta_{1} x\right)$ :

$$
p(N P=1)=\frac{1}{1+e^{-\left(\beta_{0}+\beta_{1} x\right)}}=F(x),
$$

where $p(x)$ is the probability of non-performance $N P=1$, given some linear combination of a vector of predictors $x$, with $e$ denoting the exponential function. As the value of the linear expression can vary from negative to positive infinity, after transformation, the resulting probability $p(x)$ ranges between 0 and $1 . \beta_{0}$ is the intercept from the linear equation, $\beta_{1}$ a vector of coefficients.

A logistic regression is performed to find the $\beta$ parameters that best fit: 


$$
N P=\left\{\begin{array}{ll}
1 & D^{\prime}=\beta_{0}+\beta_{1} x+\varepsilon \geq 0 \\
0 & D^{\prime}=\beta_{0}+\beta_{1} x+\varepsilon<0
\end{array},\right.
$$

where $\varepsilon$ is an error distributed by the standard normal distribution in case of a probit model. The associated latent variable is $N P^{\prime}=\beta_{0}+\beta_{1} x+\varepsilon$ where both $N P^{\prime}$ and $\varepsilon$ are unobserved, hence 'latent'. We assume that among the predictors $X$ are the loan-tovalue ratio $(O L T V)$, the debt-service-to-income ratio $(D S T I)$, and other control variables $Z$.

$$
p(N P=1)=F\left(L T V_{i}, D S T I_{i}, Z_{i}\right)
$$

Our a priori expectations are that both OLTV and DSTI positively affect the NP-probability. Control variables $Z$ contain borrower-specific or dwelling controls including borrower age, applicant employment status, presence of a Dutch mortgage guarantee, binary indicator of underwater status, purpose of the loan, loan type, as introduced in Sect. 3.1.

\section{Results}

Table 4 gives the estimation results for the logit model relating the NP-status to the explanatory variables introduced above. Two interaction terms have been added to the model, the second interacting OLTV with NHG and the second interacting DSTI with NHG. The purpose of this interaction is to examine differences between NHG and non-NHG holders with respect to the determinants of non-performance.

The first column gives the estimated coefficients, the magnitudes of which are not easy to interpret in terms of probability effects. Therefore, for ease of interpretation, the marginal effects of the explanatory variables are also given, being the partial derivatives of the probability with respect to the explanatory variables evaluated at their respective means. The advantage of marginal effects is that they are directly interpretable in terms of the implied effect of each variable on the NP-probability.

\subsection{OLTV, DSTI and NHG}

The estimate of 0.019 for the marginal effect of the OLTV ratio means that if the OLTV ratio is 0.1 (or 10 percentage points) higher, the NP-probability increases by 0.0019 (or 0.19 percentage point). This is both statistically significant and economically significant, as the mean NP-rate is 1.7 percent. Back of the envelop, this implies that the proposals of the IMF (and DNB) to reduce the LTV cap to $80 \%$ (90\%) (see Verbruggen et al. 2015), would reduce the NP-rate from $1.7 \%$ to $1.3 \%(1.5 \%)$, which is a $22 \%(11 \%)$ reduction in the NP-rate. The marginal effect of the NHG dummy is -0.005 , which means that NHG loans on average run 0.5 percent lower risk of non-performance. Figure 5, panel A, depicts the predicted non-performance probabilities for mortgage loans with and without NHG for different OLTV ratios. The dotted lines denote $95 \%$ confidence intervals. The difference between the two NP probability lines, around 0.005 or 0.5 percentage point, 
Table 4 Logit estimation results for residential mortgage loan

\begin{tabular}{lll}
\hline Explanatory variable & Coefficients & Marginal effects \\
\hline Originating loan to value ratio & $1.163^{* * *}$ & $0.019^{* * * *}$ \\
& $(0.023)$ & $(0.000)$ \\
Debt service to income ratio & $4.601^{* * *}$ & $0.075^{* * *}$ \\
& $(0.174)$ & $(0.003)$ \\
NHG & $-0.486^{* * *}$ & $-0.005^{* * *}$ \\
& $(0.063)$ & $(0.000)$ \\
Age loan applicant & $-0.008^{* * *}$ & $-0.0001^{* * *}$ \\
& $(0.001)$ & $(0.000)$ \\
Under water status & $0.678^{* * *}$ & $0.011^{* * *}$ \\
& $(0.014)$ & $(0.000)$ \\
Self-employment status loan applicant & $0.545^{* * *}$ & $0.009^{* * *}$ \\
& $(0.019)$ & $(0.000)$ \\
Interest only loan share & $0.359^{* * *}$ & $0.006^{* * *}$ \\
& $(0.024)$ & $(0.000)$ \\
House partly commercially used & $0.309^{* * *}$ & $0.005^{* * *}$ \\
& $(0.098)$ & $(0.002)$ \\
Interaction terms & & \\
NHG * Originating Loan to Value ratio & $0.149^{* * *}$ & \\
NHG * Debt service to income ratio & $(0.051)$ & \\
Pseudo R & 0.297 & \\
Correctly classified (\%) & $(0.319)$ & \\
AUROC & 0.051 & \\
Number of borrowers & 98.4 & \\
\hline Depentent vario & 0.699 & \\
& $1,590,494$ & \\
& & \\
& &
\end{tabular}

Dependent variable is non-performance dummy

Robust standard errors are shown within parentheses. Marginal effects are evaluated at the mean values of the explanatory variables. Originating Loan to Value ratio is the Loan To Value ratio at origination of the loan. For second line loans this is the combined or total OLTV. Debt service to income ratio (DSTI) only takes mortgage debt into account (see "Appendix B" for more details). Age loan applicant is the age at origination of the mortgage. The underwater status is a dummy equal to 1 if the current valuation amount is larger than the current principal. Self-employment is measured at loan application. Share of interest only (IO) loans is defined using the sum of these loan types divided by total debt. IO loans are separately identified as being a bullet loan

*** Indicates statistical significance at $1 \%$

See "Appendix A" for variables' definitions

reflect the marginal effect of the NHG, but the difference is greater (smaller) for higher (lower) OLTV ratios. This means that NHG loans not only have lower NPprobabilities but that the sensitivity for higher OLTVs is also somewhat smaller.

The marginal effect for the debt service to income ratio (DSTI) is 0.075 meaning that if the DSTI ratio increases by 0.1 or 10 percentage points, the NP-probability increases by 0.0075 or 0.75 percentage point. Figure 5 , panel B, also shows that the difference between the two lines is around 0.005 or 0.5 percentage point, 


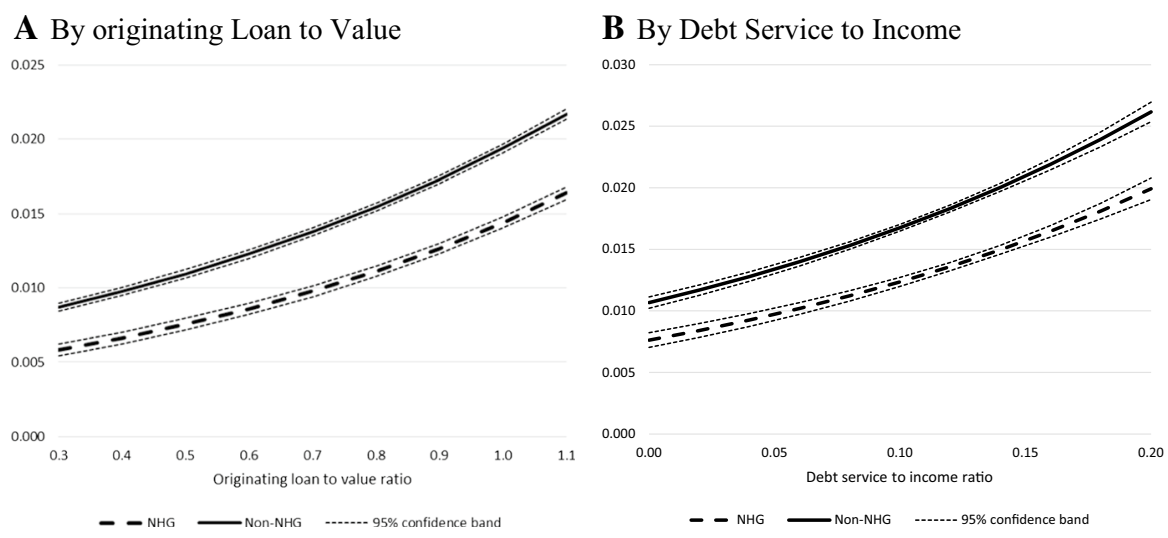

Fig. 5 Predicted non-performance probabilities for mortgage loans with and without NHG, by originating loan to value and debt service to income ratio. a By originating loan to value $\mathbf{b}$ by debt service to income

but greater (smaller) for higher (lower) DSTI ratios. Hence, NHG loans not only have lower NP-probabilities but are also less sensitive to higher DSTIs.

The shapes of the predicted NP-probability curves in Fig. 5 are convex, which is typical for exponential logit functions. The curves are smooth and have no kinks, because each explanatory variable in the logistic regression equation has only one coefficient. An alternative approach, which allows for varying coefficients for an explanatory variable, is to use a spline function which fits a piecewise regression between specific points, known as knots, of the continuous variable. Following a number of applications in the medical literature, Kelly and O'Toole (2019) applied a restricted cubic spline in their analysis of defaults of UK buy-to-let loans. We adopt their approach by also allowing for a non-linear relationship between the knots using the restricted cubic spline. When using a restricted cubic spline, one obtains a continuous smooth function that is linear before the first knot, a piecewise cubic polynomial between adjacent knots, and linear again after the last knot. In general, the logit restricted cubic spline model, with restricted spline function $\mathrm{f}(\mathrm{SV})$, with $k$ knots is given by:

$$
p(N P=1)=F\left(L T V_{i}, D S T I_{i}, Z_{i}, f\left(S_{V}\right)\right) .
$$

with $f\left(S_{V}\right)=\beta_{0}+\beta_{1} S_{V 1}+\beta_{2} S_{V 2}+\cdots+\beta_{k-1} S_{V k-1}$ and the other variables as defined in Eq. (3). $S_{V}$ represents the variable $V$ upon which the spline function is applied. In our case, this relates to two variables: OLTV and DSTI. We adapt the default five equally spaced percentiles recommended by Harrell (2001), i.e., the knots are located at the 5, 27.5, 50, 72.5 and 95 percentiles of the distributions of OLTV and DSTI. This is in line with Kelly and O'Toole (2019).

The predicted NP probability curves for OLTV (see Fig. 6) based on the spline functions do exhibit some degree of non-convexity. The NP probability curve for non-NHG loans stays low for OLTVs lower than $60 \%$, but it bends steeply upwards 

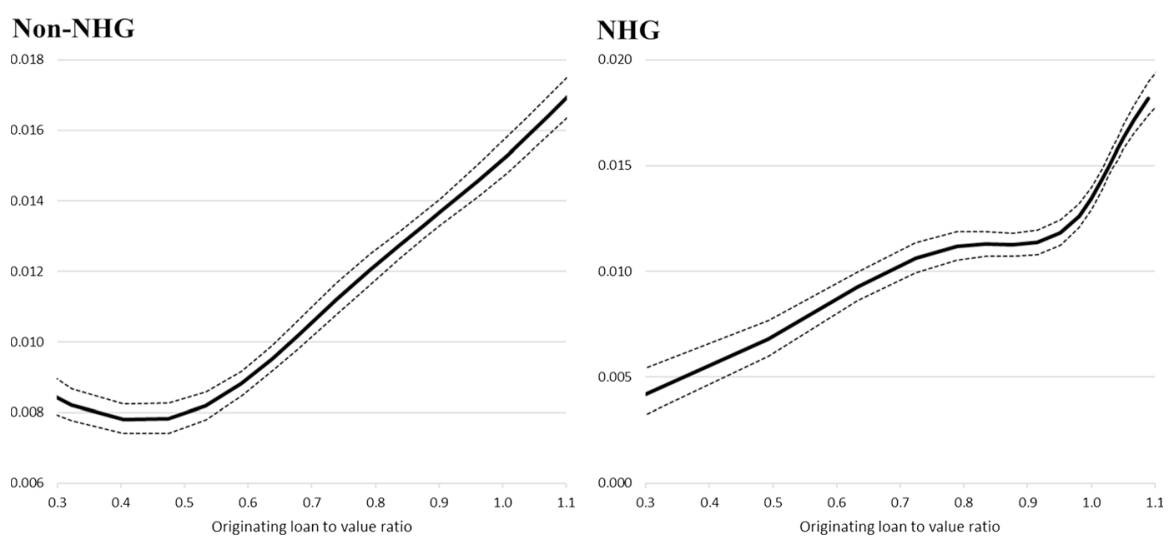

Fig. 6 Predicted non-performance probabilities using cubic spline functions, for mortgage loans with and without NHG, by originating Loan to Value ratio
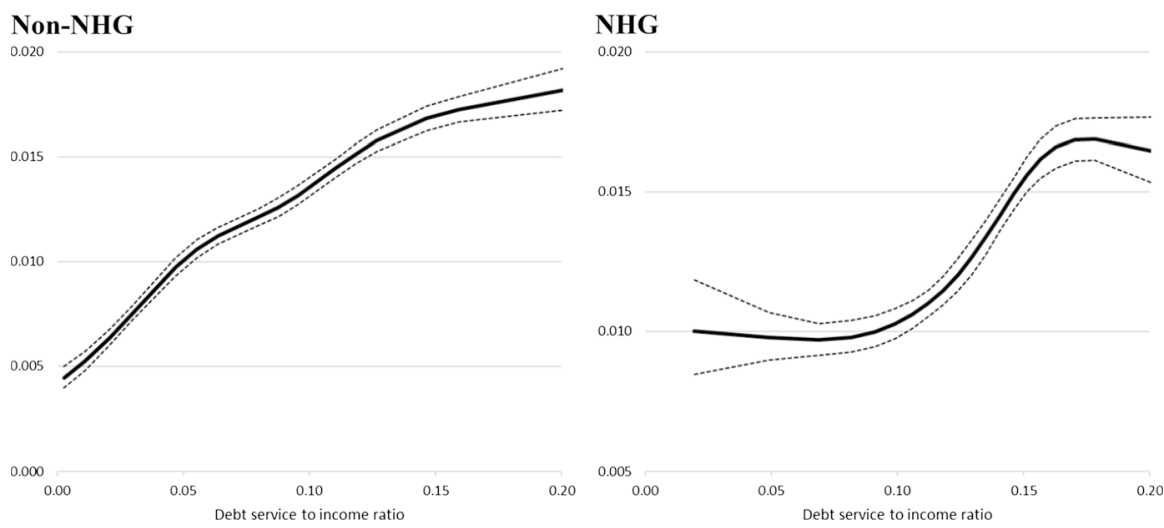

Fig. 7 Predicted non-performance probabilities using cubic spline functions, for mortgage loans with and without NHG, by Debt Service to Income ratio

for OLTVs $>70-80 \%$. Notice that the $80 \%$-threshold has some practical applications in risk management; for instance, it is typically a requirement for securitization, a popular practice in the Netherlands in our sample period. For NHG-loans, the NP probability curve is concave until an OLTV of 80-90\%. However, when the OLTV increases beyond the 80-90\% threshold, the NP curve becomes convex and bends steeply upwards.

What information do these estimates provide in terms of calibrating prudential LTV caps? The shapes of the spline-based probability curves for OLTV suggest that LTV caps could be different for secured and non-secured loans. Specifically, it seems that an LTV cap for insured mortgages could be as high as $90 \%$, whereas an LTV cap for uninsured mortgages should be set at $70-80 \%$ to prevent non-performance probabilities from accelerating. 
Table 5 Robustness analysis of selected marginal effects by subgroup

\begin{tabular}{lllr}
\hline & $\begin{array}{l}\text { Originating Loan to } \\
\text { Value ratio }\end{array}$ & $\begin{array}{l}\text { Debt service to } \\
\text { income ratio }\end{array}$ & $\mathrm{N}$ \\
\hline Baseline specification & $0.0193 * * *$ & $0.0748 * * *$ & $1,590,494$ \\
Largest 3 banks only & $0.0194 * * *$ & $0.0763 * * *$ & $1,447,092$ \\
Smaller banks & $0.0201 * * *$ & $0.0487 * * *$ & 143,330 \\
Age borrower $<48$ & $0.0254 * * *$ & $0.0732 * * *$ & 766,857 \\
Age borrower $>=48$ & $0.0133 * * *$ & $0.0759 * * *$ & 872,976 \\
Original mortgage $<=125000$ EUR & $0.0153 * * *$ & $0.0675 * * *$ & 383,397 \\
Original mortgage $>125000$ EUR & $0.0206 * * *$ & $0.0871 * * *$ & $1,256,436$ \\
Collateral located in one of the 4 larger & $0.0323 * * *$ & $0.0670 * * *$ & 164,246 \\
$\quad$ municipalities & & & $1,475,587$ \\
\hline Collateral located elsewhere & $0.0174 * * *$ & $0.0795 * * *$ & \\
\hline
\end{tabular}

***Indicates statistical significance at $1 \%$. Subgroup regressions are based on models including the borrower's current age instead of the applicant's age at origination of the loan

Figure 7 gives spline-based NP probability curves for DSTI. The shapes of the NHG and non-NHG curves differ: the non-NHG curve is weakly concave, with NP probability rising from $0.5 \%$ for DSTI $=0$ to $1.8 \%$ for DSTI of $20 \%$. In contrast, the NHG-curve has an S-shape: NP probability is constant at $1.0 \%$ for DSTIs until $10 \%$, it rises strongly upwards to a level of $1.7 \%$ for a DSTI of $17 \%$ after which it remains flat for higher DSTIs. This difference in shapes between NHG and non-NHG is likely related to the DSTI rule for NHG insurance discussed in Sect. 3: NHG can be bought only by borrowers with a proportion of income which is spent on housing below a certain limit. Hence, NHG insurance implies a cap on DSTI is already present for most cases.

What information do these estimates provide in terms of calibrating prudential DSTI caps? For NHG loans, DSTI caps are already present. For non-NHG loans, there is no clear kink in the NP probability curve which means there is no clear indication of where a DSTI cap could best be calibrated.

\subsection{Other Explanatory Variables}

Older borrowers have lower credit risk. The marginal effect is small, however $(-0.01$ percentage point per year). Borrowers whose houses are 'under water' run higher risk of non-performance. The marginal effect is 1.1 percentage point. Borrowers who were self-employed when taking on the loan, run higher risk of nonperformance. The marginal effect is 0.9 percentage point. Interest only loans have somewhat higher credit risk. The marginal effect of the interest only loan share is 0.6. The purpose of the main loan is also a determining factor for credit risk. If loans were mainly taken on houses that were partly commercially used, credit risk was 0.5 percentage point higher. 


\subsection{Robustness Checks}

Table 5 shows the marginal effects of several specifications for selected subgroups and compares them to the baseline specification. It aims at comparing the effects of the main default triggers for different subgroups.

Banks characteristics could affect the effects of the main triggers on non-performance, for instance the OLTV. One such characteristic is bank size, as larger banks could be seen as being more 'distant' from borrowers, while smaller banks could be better at screening or monitoring as they are closer to their customers. In the Netherlands though, the banking system is highly concentrated (see Table 1), and so the results for the three largest banks are almost identical to the baseline results. For smaller banks, we observe economically similar results, though their statistical significance is different.

In Table 5, we also show a specification of the model in which we use the age of the borrower, rather than the age of the applicant at origination. Current age could also affect the relationship between OLTV and non-performance, for instance because some unobserved variables, such as financial wealth, are differently distributed across cohorts. The results show that the effect of the OLTV is twice as large for younger cohorts, who indeed typically have smaller buffers. A similar reasoning could apply for houses with smaller mortgages. These have typically been purchased at times when prices were lower, so by currently older borrowers, and our results show indeed a smaller effect of OLTV for this group. Finally, the larger effect of OLTV in the 4 larger municipalities could be related to the fact that younger professionals are attracted by big cities or to the larger price fluctuations observed in municipal areas.

As for the other risk trigger in Table 5, the DSTI show very little differences in marginal effects. Despite the large relative changes in some cases (for instance across different bank sizes) these effect stay consistently small.

\section{Summary and Conclusions}

Using loan level data on residential mortgage loans originated by all Dutch banks during 1996 to 2015, we analyse the determinants of the incidence of non-performance, i.e., arrears or defaults.

We find that both the originating loan to value ratio (OLTV) and the debt-serviceto-income ratio (DSTI) are significantly positively associated with the probability of mortgage arrears. The results also suggest that mortgages with government backed debt insurance (NHG) perform better. Moreover, several mortgage loan and borrower characteristics, such as the (interest only) loan type and the underwater status of the borrower, increase credit risk. The age of the borrower diminishes credit risk. The loan purpose is also a significant determinant: in case the financing of a commercially used property, credit risk is higher. These effects are relatively robust across different segments of the population, but the results also show that younger borrowers, who are more likely to reside in larger cities and to have higher debt, show a stronger relation between the OLTV and non-performance. 
The estimates also provide information in terms of calibrating prudential LTV caps. The shapes of the spline-based probability curves for OLTV suggest that LTV caps could be different for secured and non-secured loans. Specifically, it seems that an LTV cap for insured mortgages could be as high as $90 \%$, whereas an LTV cap for uninsured mortgages should be set at $70 \%$ to $80 \%$ to prevent non-performance probabilities from accelerating.

Open Access This article is licensed under a Creative Commons Attribution 4.0 International License, which permits use, sharing, adaptation, distribution and reproduction in any medium or format, as long as you give appropriate credit to the original author(s) and the source, provide a link to the Creative Commons licence, and indicate if changes were made. The images or other third party material in this article are included in the article's Creative Commons licence, unless indicated otherwise in a credit line to the material. If material is not included in the article's Creative Commons licence and your intended use is not permitted by statutory regulation or exceeds the permitted use, you will need to obtain permission directly from the copyright holder. To view a copy of this licence, visit http://creativecommons.org/licen ses/by/4.0/.

\section{Appendix A: Variable Definitions}

The data collection of DNB is based on the ECB templates that is used for the European Data Warehouse RMBS data. However, we have slightly modified some definitions in order to guarantee consistency over time.

\begin{tabular}{ll}
\hline Variable & Definition \\
\hline Non-performing (NP) & $\begin{array}{c}\text { Account status equal to default/foreclosure or arrears. We take this } \\
\text { indicator at collateral level, so if only one of the loans linked to a } \\
\text { specific collateral is defaulted, we assume that the borrower who } \\
\text { owns that collateral is in default }\end{array}$ \\
Originating loan to value ratio & $\begin{array}{l}\text { Loan To Value ratio at origination of the loan. For second line loans } \\
\text { this is the combined or total OLTV }\end{array}$ \\
Debt service to income ratio & $\begin{array}{l}\text { See "Appendix B" } \\
\text { NHG }\end{array}$ \\
Nationale Hypotheek Garantie, i.e. mortgage debt insurance. Type of \\
guarantee provider being the Waarborgfonds Eigen Woning \\
Under water status \\
Age of main applicant \\
A dummy equal to 1 if the current valuation amount is larger than the \\
current principal. Definition net of pledged saving accounts, when \\
these are proxied using inception date rather than origination date. \\
We apply a 2\% haircut to the current valuation amount, which is an \\
indexed value relative to the original valuation using local indexes \\
provided by Statistics Netherlands \\
Self-employed status of the primary applicant at origination \\
This loan type is separately identified as being a bullet loan. These \\
loans do not amortize and thus do not have a maturity date. For \\
borrowers with multiple loans, the share of interest only in the total \\
is used
\end{tabular}

House partly commercially used A dummy equal to 1 if the house is (partly) commercially used 


\section{Appendix B: Assumptions Made for Calculation of Debt Service to Income (DSTI) Ratio}

The DSTI ratio is not reported in the LLD template. We thus define a mortgage DSTI ratio that only takes mortgage debt into account. We need to tackle two main challenges. First, periodic payments are not well defined in the template and often only report the payments received by the bank (typically only interest) and not the amortization or the savings deposits. Second, income is only observed at origination. Below, a detailed explanation of how we deal with both issues is given. The mortgage DSTI is then computed as being equal to the ratio between the monthly total net periodic payments on all loan parts of the borrower, divided by the borrower's net monthly current income.

\section{Periodic Payments}

In order to have a clear indication of periodic payments, we must distinguish among the different loan types. In the scheme below, we explain how we deal with each loan type. We kept the notation simple, but some of the variables listed below contain more detailed information. Specifically, the marginal tax rate for the mortgage interest deduction (tax) is individual and time specific. This is relevant because exogenous changes to tax policy have taken place. From 2012 the marginal tax rate was progressively reduced in steps of $0.5 \%$ points to borrowers with higher incomes. So, over time, the net period payments of these borrowers, have increased, ceteris paribus. This reform has the advantage to bring additional heterogeneity into the model.

\begin{tabular}{ll}
\hline Loan type & Net periodic payment $(N P P)$ \\
\hline Interest only loan & $N P P=P * r *(1-\operatorname{tax})$ \\
Annuity or linear loan & $A P=\left(\frac{r}{1-(1+r)^{\text {length }}}\right) * P$ \\
& $A A=A P-r$ \\
Saving or life-insurance loan & $N P P=A A+R P * r *(1-\operatorname{tax})$ \\
& $S P=\frac{P}{\frac{1-\left((1+r)^{-1}\right)^{\text {length }}}{1-\left((1+r)^{-1}\right)}}$ \\
Investment loan & $N P P=S P+P * r *(1-\operatorname{tax})$ \\
& $I P=\frac{P}{\left(1+\left((1+k)^{\text {length }}\right.\right.}$ \\
& $\left.N P P=I P+P * r *(1+k)^{-1}\right)$ \\
\hline
\end{tabular}

$P=$ principal, $r=$ interest rate on loan, $\operatorname{tax}=$ marginal tax rate of mortgage interest deduction, $A P=$ annuity premium, length = difference in years between maturity date and origination date, $A A=$ annuity amortization, $R P=$ residual annuity debt after amortization, $S P=$ Saving premium, $I P=$ investment premium (how much is transferred to investment fund each period), $k=$ expected return from investment $=8 \%$ (this is the maximum expected return that brokers could use according to tax law) 


\section{Current Income}

In the LLD, we only observe income at loan origination. This is a household income, in the sense banks either report the sum of the incomes of the borrowers (if they are a couple) or the separate incomes of the two members of the couple. For the computation of the mortgage DSTI, we need current income, but this is not observed. In order to proxy current income, we apply a wage inflation to original income from the date of origination to the present day. This means that all households receive the mean wage increase in each period. This is of course an overestimation for those who might lose their jobs or decide to work part-time. At the same time this could be an underestimation for those households where one starts working more or experiences a promotion. These measurement errors might cancel out each other to some extent, and become possibly more severe, the older the loan. In the LLD however, $50 \%$ of the loans have originated in the last 7 years, due to the frequent resets.

The resulting DSTI is trimmed by deleting the $1^{\text {st }}$ and $99^{\text {th }}$ percentile of the distribution, assuming that these extreme values are outliers that may be due to mismeasurement.

\section{References}

Ampudia, M., van Vlokhoven, H, Zochowski, D. (2014). Financial fragility of euro area households. In ECB Working Paper No. 1737.

De Haan, L. (2003). Microdata evidence on the bank lending channel in the Netherlands. De Economist, 151(3), 293-315.

De Nederlandsche Bank. (2018). Strong correlation between consumption and house prices in the Netherlands, DN Bulletin 25 January. https://www.dnb.nl/en/news/news-and-archive/DNBulletin 2018/dnb371605.jsp.

Galati, G., \& Moessner, R. (2018). What do we know about the effects of macroprudential policy? Economica, 85(340), 735-770.

Geanakoplos, J. (2009). The leverage cycle. In: D. Acemoglu, K. Rogoff, M. Woodford (Eds.) NBER macroeconomics annual 2009, vol. 24, University of Chicago Press, pp. 1-65.

Gerlach-Kristen, P., \& Lyons, S. (2018). Determinants of mortgage arrears in Europe: Evidence from household microdata. International Journal of Housing Policy, 18(4), 545-567.

Guiso, L., Sapienza, P., \& Zingales, L. (2013). The determinants of attitudes toward strategic default on mortgages. The Journal of Finance, 68(4), 1473-1515.

Harrell, F. E., Jr. (2001). Regression modeling strategies: With applications to linear models, logistic regression, and survival analysis. New York: Springer.

Japelli, T., Pagano, M., di Maggio, M. (2008). Households' indebtedness and financial fragility. Centre for Studies in Economics and Finance Working Paper No. 208.

Kakes, J., Loman, H., \& Van der Molen, R. (2017). Verschuivingen in de financiering van hypotheekschuld. Economische Statistische Berichten, 102(4749S), 69-73.

Kelly, R., \& O’Toole, C. (2019). Mortgage default, lending conditions and macroprudential policy: Loan-level evidence from UK buy-to-lets. Journal of Financial Stability, 36, 322-335.

Kim, Y., Mastrogiacomo, M., Hochguertel, S., Bloemen, H. (2018). Till debt do us part: Strategic divorces, economic outcomes and a test of moral hazard. Netspar Industry Paper forthcoming.

Lea, M. (2011). Alternative forms of mortgage finance: What can we learn from other countries? In AREUEA annual conference paper. 
Li, W., \& Oswald, F. (2017). Recourse and residential mortgages: The case of Nevada. Journal of Urban Economics, 101, 1-13.

Mastrogiacomo, M., \& van der Molen, R. (2015). Dutch mortgages in the DNB loan level data. DNB Occasional Study 4.

Mian, A., Rao, K., \& Sufi, A. (2013). Household balance sheets, consumption, and the economic slump. Quarterly Journal of Economics, 128(4), 1687-1726.

Mian, A., \& Sufi, A. (2009). The consequences of mortgage credit expansion: Evidence from the US mortgage default crisis. Quarterly Journal of Economics, 124(4), 1449-1496.

Ronald, R., \& Dol, K. (2011). Housing in the Netherlands before and after the global financial crisis. In R. Forrest and N.-M. Yip (eds.), Housing markets and the global financial crisis: The Uneven impact on households. Edward Elgar.

Stanga, I., Vlahu, R., de Haan, J. (2017). Mortgage arrears, regulation and institutions: Cross-country evidence. In DNB working paper 580.

Verbruggen, J., van der Molen, R., Jonk, S., Kakes, J., Heeringa, W., Dicou, D., van Dijk, D., de Haan, L., Jansen, D.-J., Jong, J., Mastrogiacomo, M., de Veirman, M. (2015). Effects of further reductions in the LTV limit, DNB Occasional study, 13-2.

Wong, E., Fong, T., Li, K., Choi, H. (2011). Loan-to-value ratio as a macroprudential tool—Hong Kong SAR's experience and cross-country evidence. In Hong Kong Monetary Authority Working Paper 01/2011.

Publisher's Note Springer Nature remains neutral with regard to jurisdictional claims in published maps and institutional affiliations. 